\title{
Attitude and Self-confidence Students in Learning Natural Sciences: Rural and Urban Junior High School
}

\author{
Astalini $^{1}$, Dwi Agus Kurniawan ${ }^{1, *}$, Darmaji ${ }^{1}$, Muhammad Ikhlas ${ }^{2}$, Kuswanto $^{2}$, Rahmat Perdana ${ }^{1}$, \\ Lika Anggraini ${ }^{1}$, Iwan Putra ${ }^{1}$
}

${ }^{1}$ Faculty of Teaching and Education, Universitas Jambi, Jambi, Indonesia

${ }^{2}$ Collage of Education, Central Luzon State University, Nueva Ecija, Philippines

Received March 26, 2020; Revised April 23, 2020; Accepted May 3, 2020

Copyright $\bigcirc 2020$ by authors, all rights reserved. Authors agree that this article remains permanently open access under the terms of the Creative Commons Attribution License 4.0 International License

\begin{abstract}
Purpose: This paper presents junior high school students' attitudes and self-confidence in learning natural science, and compares the attitudes and self-confidence based on location of school in urban and rural areas, and finds whether attitudes can affect students' self-confidence. Methodology: The study used mixed method with sequential explanatory. A sample of this study is 926 students with 511 for urban junior high school and 415 for rural junior high school usage total sampling technique. Data were then analyzed with the help of the SPSS 21 application to find descriptive statistics in terms of mean, min, max, and simple regression and independent sample t-test. Finding: Both of school location in urban and rural area, shows that attitudes and self-confidence of the students was good category, but when comparing that results, independent sample t- shows if students attitude and self-confidence in urban schools tend more higher than in rural schools $(p<0.001)$. Lastly, the regression shows if the level of contribution or influence of students' attitudes towards students' self-confidence is as much as $75.2 \%$ which means that students' attitudes affect students' self-confidence. Novelty: in this study, it was found that students' attitudes affect self-confidence of students' in learning natural sciences. Moreover, comparison between students' attitudes and self-confidence is based on their school location in urban or rural.
\end{abstract}

Keywords Attitude, Natural towards Science, Urban, Rural, Self-confidence

\section{Introduction}

Education is the process of acquiring or imparting knowledge and skills [1]; [2]. Education is a knowledge or a place of learning that is very important knowledge owned by everyone, in order to have a good mindset and good behavior as well. Education is a conscious planned effort in the learning process that allows learning to develop potential and skills [3]. One level of education in Indonesia is the junior high school level. At this level, student study various sciences, one of them is the natural science subject. On this subject, student learn and discuss about natural objects with definite, concepts and general laws, applicable whenever and wherever, and also phenomena in everyday life [4]; [5].

In learning, students are required to be active in the class and skilled in thinking, in the demands that there are aspects of cognitive, affective and psychomotor. In the aspect of cognitive attitude is the ability to think intellectually which has a level of knowledge, development, understanding, abilities and intellectual second ills [6]; [7]. It means that attitudes toward science are very important for students in intelligence in thinking and acting as problem-solving [8]. Students must also have effective aspects, this affective component is the same as behavior that refers to an evaluation or an emotional response to the object of attitude and is generally regarded as the core of attitudes. in addition to effective aspects, students must also have a skilled aspect in thinking or called the psychomotor aspect. Based on this attitude of students towards the subject of science is very important, because it has a positive impact on learning [9]; [10].

Students who have a positive attitude toward the learning of science means that students love the learning. Attitudes toward science are necessary because it will affect the learning process, one of the learning outcomes. It can be said that students are positive when they are able to deeply understand the concepts of science and make learning more effective in their environment [11]. In addition, students also have a negative attitude toward the learning of science, it would make learning in the future will be complicated. When students have a poor attitude towards learning will affect the level of thought to seek information that can solve a physical problem [12]; [13]. Positive attitudes of students towards the subject of science will be related to the attitude of investigation, the adoption of a scientific attitude, the pleasure in learning.

Attitudes toward investigation is a scientifically resolvable problem. Some ways of measuring, identifying and experimenting are on a scientific scale to find strong 
information [14]. In this investigation activity, students are required to seek more scientific information on the learning process. It is intended that the students can find out for themselves the information in conducting the experiment. In conducting experiments students can understand conceptual knowledge. An experiment in scientific investigation refers to questions that are answered in a structured way [15]. Attitudes toward the science investigation are very positive for students in terms of doing experiments and students are more likely to be active.

While conducting an inquiry, students are trying to focus on experimenting, this can be said of the adoption of a scientific attitude. In that focus, students can be attentive, diligent, tenacious and earnest in scientific attitude investigation. Scientific attitude can be expressed by the attitude of science [16]. Scientific attitudes play a major role in the educational and life sciences of students pursuing educational science. In the learning process, students can perform a scientific attitude well when students understand the concept and critical problems in solving diligently in learning. This is said to be a very influential scientific attitude in the teaching-learning process involving students' attitudes toward science such as personality and curriculum [17]; [18]. Scientific attitude has good habits of thinking, in addition to improving student achievement in the learning process.

Pleasure in the process of learning is also a concern during the learning process, but often in the science is very difficult. So students who have fun in learning are very few. There is fun in science lessons if students know how to plan and implement solution strategies for questions through teaching methods [18]. Students who are happy in science learning will have curiosity about their learning. In addition, science learning will feel good when students have more intensive character [19]; [21]. In the learning process, students are happy when the material they learn is interesting and provides longer study time. In the learning process, the group of students looks active in learning. Then at the time of the experiment students can use the tool, string tools and get the data well. Besides how to develop student's pleasure to learning is to make the classroom more comfortable and have skill development [22]. Students who love to learn science will be interested to learn and increase study time longer.

Based on the above indicators the attitude plays an important role in the process of learning to reflect student behavior in learning. Through the attitude of students having an interest in science, students can be identified science issues that are relevant to the real world as well as the relationship of mathematical equations and concepts in science [23]; [24]. For example, in teaching teachers to explain concepts and mathematical equations, students are expected to understand and apply in the daily life of learning. These students have a negative and positive attitude towards the subject. Negative attitude of students feel bored and sleepy in learning, positive attitude of students diligently work on the problem and act in the classroom. In order to succeed in the attitude, then the teacher should use the strategies and methods of learning that are good at improving student attitudes. They have highlighted that they are happy in science lessons if students know how to plan and implement solution strategies for questions through teaching methods [25].

A student's self-confidence in learning is very important, as is the case with natural sciences learning. [23] Students who have good confidence, have positive feelings about themselves, have strong beliefs about themselves and have accurate knowledge of their abilities so they are able to develop their knowledge and talents [26]

The attitude and self-confidence of a student in learning natural sciences must be good, so that later learning followed by students tends to be easy, easy to follow and get good results later on [23]. With the same subjects, as well as the same taught material, perceptions of attitude and self-confidence of both students who study in urban areas and those in rural areas should be the same in learning natural sciences. But the reality is not certain, because many factors affect learning, one of which is an environmental factor or location of the school.

Based on that, the purpose of this study is to describe the attitudes and self-confidence of students, see whether attitudes can affect students' confidence in learning, and compare whether there is a difference between attitudes and self-confidence in students who are attending school in urban and rural areas.

\section{Materials and Methods}

The research method used in this study is a mixed research method (mixed method). Mixed researched is a general type of research (It's one of the three paradigms) in which quantitative and qualitative methods, techniques, or other paradigm characteristics are mixed in one overall study [27]. The type of research used is the explanatory sequential mixture method. "An explanatory sequential mixed methods design consists of collecting quantitative data and then collecting qualitative data to help explain or elaborate on the quantitative results [27]; [28].

The sample of this research was obtained from 926 junior high school students with details of 511 for urban junior high school and 415 for rural junior high school, in Jambi Province, Indonesia, who were taken by the total sampling technique. Total sampling is a technique for sampling by using the entire population to be sampled [29]. Where, quantitative data were obtained through an attitude and confidence questionnaire, then continued with qualitative activities, namely conducting interviews with 50 students.

In this study, this study used two questionnaire instruments and interview, the interview is intended as an strengthen of the quantitative results obtained, attitude questionnaires adopted from [30] has 26 valid statements with a reliability of 0.83 , the self-confidence questionnaire was adapted from [31] with 24 valid statements with a reliability of 0.72 . The questionnaire uses a Likert scale of 5 (five).

The categories of questionnaire of attitude and self-confidence include, very good, good, enough, not good, and very not good, like table 1. 
Table 1. Categories of students' attitudes, and confidence in learning

\begin{tabular}{|c|c|c|c|c|}
\hline \multirow{2}{*}{ Category } & \multicolumn{3}{|c|}{ Interval } & \multicolumn{2}{c|}{$\begin{array}{c}\text { Self- } \\
\text { confidence }\end{array}$} \\
\cline { 2 - 5 } & \multicolumn{3}{|c|}{$\begin{array}{c}\text { Attitude } \\
\text { confidence }\end{array}$} \\
\cline { 2 - 5 } & Attitude towards investigation & $\begin{array}{c}\text { Adoption of scientific } \\
\text { attitude }\end{array}$ & Pleasure in learning & $21.0-37.8$ \\
\hline Very Not Good & $9.0-16.2$ & $7.0-12.6$ & $10.0-18.0$ & $37.9-54.6$ \\
\hline Not Good & $16.3-23.4$ & $12.7-18.2$ & $26.1-34.0$ & $54.7-71.4$ \\
\hline Enough & $23.5-30.6$ & $18.3-23.8$ & $34.1-42.0$ & $71.5-88.2$ \\
\hline Good & $30.7-37.8$ & $23.9-29.4$ & $42.1-50.0$ & $88.3-105.0$ \\
\hline
\end{tabular}

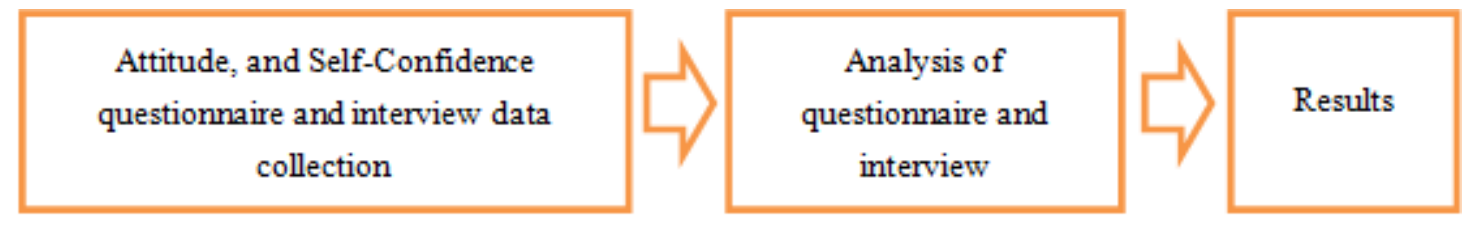

Figure 1. Data Collection

In this study the data collection procedure can be seen in Figure 1.

In the first data collection process, because it uses the type of sequential explanation, the first data obtained is quantitative data through questionnaire given to the students. Then data analysis uses the SPSS 21 application to look for descriptive statistics to view quantitative data, while qualitative data use miles \& huberman, namely data reduction, data display, and conclusions [32]. Descriptive statistics are presented in summary frequencies, such as mean, mode, median, minimum, maximum and standard deviation [27]. In this study the descriptive statistics used are mean, min, Max, and Category and the hypothesis using simple regression and independent sample $t$ test.

\section{Results}

The novelty of this study is seen from three indicators of student attitudes namely, attitude toward investigation, adoption of scientific attitude, and pleasure in learning towards self-confidence, as well as a comparison between the attitudes and self-confidence of students attending school in urban and rural areas.

Research findings are explained in this section. The category, mean, min, max, percentage, regression between two variables and comparison between rural and urban are presented as follows.

\section{Attitude towards Investigation of students in urban and rural schools}

The result of attitude data processing on the investigation in science for urban schools is showed by the table 2, meanwhile for the rural schools showed by the table 3 .

Table 2 shows attitudes toward investigation for urban schools' area as much as 926 respondents, dominated by good attitude, as many as 607 respondents. So, the student's attitude toward the investigation is categorized good. Then table 2 also states the attitude of the category is not good as much as $4.2 \%$, for the attitude of the category is enough there are $23.4 \%$. Then in the good category that is $65.6 \%$ and the last attitude is very good is $6.8 \%$. From the 926 students having a mean value of 36.6 , a maximum value is 41 , and a minimum value is 17 .

Table 2. Attitude towards investigation in urban junior high school

\begin{tabular}{|c|c|c|c|c|c|c|}
\hline \multicolumn{3}{|c|}{ Classification } & \multirow{2}{*}{ Mean } & \multirow{2}{*}{ Min } & \multirow{2}{*}{ Max } & \multirow{2}{*}{$\%$} \\
\hline Range & Attitude & Total & & & & \\
\hline $\begin{array}{l}9.0- \\
16.2\end{array}$ & $\begin{array}{l}\text { Not very } \\
\text { good }\end{array}$ & 0 & \multirow{5}{*}{36.8} & \multirow{5}{*}{18} & \multirow{5}{*}{42} & 0.0 \\
\hline $\begin{array}{c}16.3- \\
23.4\end{array}$ & Not good & 39 & & & & 4.2 \\
\hline $\begin{array}{c}23.5- \\
30.6\end{array}$ & Enough & 217 & & & & 23.4 \\
\hline $\begin{array}{c}30.7- \\
37.8\end{array}$ & Good & 607 & & & & 65.8 \\
\hline $\begin{array}{c}37.9- \\
45.0 \\
\end{array}$ & $\begin{array}{l}\text { Very } \\
\text { good }\end{array}$ & 63 & & & & 6.8 \\
\hline Total & & 926 & & & & 100 \\
\hline
\end{tabular}

Afterward, table 3 shows attitudes toward investigation for rural schools' area as much as 926 respondents, dominated by good attitude, as many as 505 respondents. So, the student's attitude toward the investigation is categorized good. Then table 2 also states the attitude of the category is not good as much as $5.5 \%$, the attitude of the category is enough as there are $35.2 \%$. Then in the good category that is $54.5 \%$ and the last attitude is very good is $4.8 \%$. From the 926 students having a mean value of 33.5 , a maximum value is 41 , and a minimum value is 16 . 
Table 3. Attitude towards investigation in rural junior high school

\begin{tabular}{|c|c|c|c|c|c|c|}
\hline \multicolumn{3}{|c|}{ Classification } & \multirow{2}{*}{ Mean } & \multirow{2}{*}{ Min } & \multirow{2}{*}{ Max } & \multirow{2}{*}{$\%$} \\
\hline Range & Attitude & Total & & & & \\
\hline $\begin{array}{l}9.0- \\
16.2\end{array}$ & $\begin{array}{l}\text { Not very } \\
\text { good }\end{array}$ & 0 & \multirow{5}{*}{33.5} & \multirow{5}{*}{16} & \multirow{5}{*}{41} & 0.0 \\
\hline $\begin{array}{c}16.3- \\
23.4\end{array}$ & $\begin{array}{c}\text { Not } \\
\text { good }\end{array}$ & 51 & & & & 5.5 \\
\hline $\begin{array}{c}23.5- \\
30.6\end{array}$ & Enough & 326 & & & & 35.2 \\
\hline $\begin{array}{c}30.7- \\
37.8\end{array}$ & Good & 505 & & & & 54.5 \\
\hline $\begin{array}{c}37.9- \\
45.0\end{array}$ & $\begin{array}{l}\text { Very } \\
\text { good }\end{array}$ & 44 & & & & 4.8 \\
\hline TOTAL & & 926 & & & & 100 \\
\hline
\end{tabular}

Interview results say students in categorize well-known students can find out for themselves new things, accept opinions of others, and like to do experiments. Can be seen from the results of the interview below.

"Do you like experiment/experiment?"

"Yes I like experiment/experiment." (U)

"Do you find out your own answers when doing experiments or ask for answers from friends/teachers? Explain!"

"I find by myself without asking a friend or teacher. because it can assess how far we know about the experiment. but I received an appeal from others when I was wrong in experimenting." (U)

"Do you like experiment/experiment?"

"I am very interested in experiments, because teachers do not always carry out experiments." ( $R$ )

"Do you find out your own answers when doing experiments or ask for answers from friends/teachers? Explain!"

"I found the answers by myself in the experimental activities, but more discussed with friends and teachers." (R)

Adoption of a scientific attitude of students in urban and rural schools

The result of adoption of a scientific attitude in natural science learning for urban schools is showed by the table 4, meanwhile for the rural schools showed by the table 5 .

Table 4. Adoption of a scientific attitude for urban junior high school

\begin{tabular}{|c|c|c|c|c|c|c|}
\hline \multicolumn{3}{|c|}{ Classification } & \multirow{2}{*}{ Mean } & \multirow{2}{*}{ Min } & \multirow{2}{*}{ Max } & \multirow{2}{*}{$\%$} \\
\hline Range & Attitude & Total & & & & \\
\hline $\begin{array}{l}7.0- \\
12.6 \\
\end{array}$ & $\begin{array}{l}\text { Not very } \\
\text { good }\end{array}$ & 0 & \multirow{5}{*}{28.6} & \multirow{5}{*}{15.5} & \multirow{5}{*}{33.5} & 0.0 \\
\hline $\begin{array}{c}12.7- \\
18.2 \\
\end{array}$ & $\begin{array}{l}\text { Not } \\
\text { good }\end{array}$ & 71 & & & & 7.7 \\
\hline $\begin{array}{c}18.3- \\
23.8\end{array}$ & Enough & 196 & & & & 21.2 \\
\hline $\begin{array}{c}23.9- \\
29.4 \\
\end{array}$ & Good & 598 & & & & 64.6 \\
\hline $\begin{array}{c}29.5- \\
35.0 \\
\end{array}$ & $\begin{array}{l}\text { Very } \\
\text { good }\end{array}$ & 61 & & & & 6.6 \\
\hline TOTAL & & 926 & & & & 100 \\
\hline
\end{tabular}

Table 4 shows the adoption of scientific attitudes for urban schools' area as much as 926 respondents, dominated by good attitude, as many as 598 respondents. So, the student's adoption of scientific attitude is categorized good. Then table 4 also states the attitude of the category is not good as much as $7.7 \%$, for the attitude of the category is enough there are $21.2 \%$. Then in the good category that is $64.6 \%$ and the last attitude is very good is $6.6 \%$. From the 926 students having a mean value of 28.5 a maximum value is 35.5 , and a minimum value is 15.5 .

Table 5. Adoption of a scientific attitude for rural junior high school

\begin{tabular}{|c|c|c|c|c|c|c|}
\hline \multicolumn{3}{|c|}{ Classification } & \multirow{2}{*}{ Mean } & \multirow{2}{*}{ Min } & \multirow{2}{*}{ Max } & \multirow{2}{*}{$\%$} \\
\hline Range & Attitude & Total & & & & \\
\hline $\begin{array}{l}7.0- \\
12.6\end{array}$ & $\begin{array}{c}\text { Not very } \\
\text { good }\end{array}$ & 0 & \multirow{5}{*}{24.3} & \multirow{5}{*}{13} & \multirow{5}{*}{31.5} & 0.0 \\
\hline $\begin{array}{c}12.7- \\
18.2 \\
\end{array}$ & $\begin{array}{c}\text { Not } \\
\text { good }\end{array}$ & 89 & & & & 9.6 \\
\hline $\begin{array}{c}18.3- \\
23.8\end{array}$ & Enough & 310 & & & & 33.5 \\
\hline $\begin{array}{c}23.9- \\
29.4\end{array}$ & Good & 497 & & & & 53.7 \\
\hline $\begin{array}{c}29.5- \\
35.0\end{array}$ & $\begin{array}{l}\text { Very } \\
\text { good }\end{array}$ & 30 & & & & 3.2 \\
\hline TOTAL & & 926 & & & & 100 \\
\hline
\end{tabular}

Afterward, table 5 shows the adoption of scientific attitudes for rural schools area as much as 926 respondents, dominated by good attitude, as many as 497 respondents. So, the student's adoption of scientific attitude is categorized good. Then table 5 also states the attitude of the category is not good as much as $9.6 \%$, for the attitude of the category is enough there are $33.5 \%$. Then in the good category that is $53.7 \%$ and the last attitude is very good is $3.2 \%$. From the 926 students having a mean value of 24.3 a maximum value is 31.5 , and a minimum value is 13 . If seen further, it is found that students' adoption of a scientific attitude in junior schools in urban areas is higher than in rural areas.

Interviews say students in categorize well-known students like to listen to different opinions. For example, students do the task of the teacher if there is a different opinion in the way of completing; the student can accept not fixated with the answer itself. This is seen from the results of the interview below.

"Do you want to listen to the opinions of others who are different? What is?"

"Yes, I want, because by listening to the opinions of others we can know what is right and wrong to be fixed." (U)

"Do you want to listen to the opinions of others who are different? What is?"

"Yes ,I want, because by listening to the opinions of others we can know what is right and wrong to be fixed." (R)

\section{Pleasure in learning}

The result of pleasure in natural science learning for urban schools is showed by the table 6 , meanwhile for the rural schools is showed by the table 7 . 
Table 6. Pleasure in learning for urban junior high school

\begin{tabular}{|c|c|c|c|c|c|c|}
\hline \multicolumn{3}{|c|}{ Classification } & \multirow{2}{*}{ Mean } & \multirow{2}{*}{ Min } & \multirow{2}{*}{ Max } & \multirow{2}{*}{$\%$} \\
\hline Range & Attitude & Total & & & & \\
\hline $\begin{array}{c}10.0- \\
18.0\end{array}$ & $\begin{array}{c}\text { Not very } \\
\text { good }\end{array}$ & 0 & \multirow{5}{*}{39.5} & \multirow{5}{*}{20.2} & \multirow{5}{*}{49.6} & 0.0 \\
\hline $\begin{array}{c}18.1- \\
26.0\end{array}$ & $\begin{array}{c}\text { Not } \\
\text { good }\end{array}$ & 87 & & & & 9.4 \\
\hline $\begin{array}{c}26.1- \\
34.0\end{array}$ & Enough & 202 & & & & 21.8 \\
\hline $\begin{array}{c}34.1- \\
42.0\end{array}$ & Good & 526 & & & & 56.8 \\
\hline $\begin{array}{c}42.1- \\
50.0\end{array}$ & $\begin{array}{l}\text { Very } \\
\text { good }\end{array}$ & 111 & & & & 12.0 \\
\hline TOTAL & & 926 & & & & 100 \\
\hline
\end{tabular}

Bable 6 shows pleasure in learning for urban schools' areas as much as 926 respondents, dominated by good attitude, yeah, 526 respondents. So, the students' pleasure in learning is categorized good. Then table 6 also states the attitude of the category is not good as much as $9.4 \%$, for the attitude of the category is enough there are $21.8 \%$. Then in the good category that is $56.8 \%$ and the last attitude is very good is $12 \%$. From the 926 students having a mean value of 39.5 a maximum value is 49.6 , and a minimum value is 20.2 .

Table 7. Pleasure in learning for rural junior high school

\begin{tabular}{|c|c|c|c|c|c|c|}
\hline \multicolumn{3}{|c|}{ Classification } & \multirow{2}{*}{ Mean } & \multirow{2}{*}{ Min } & \multirow{2}{*}{$\operatorname{Max}$} & \multirow{2}{*}{$\%$} \\
\hline Range & Attitude & Total & & & & \\
\hline $\begin{array}{c}10.0- \\
18.0 \\
\end{array}$ & $\begin{array}{c}\text { Not very } \\
\text { good }\end{array}$ & 3 & \multirow{5}{*}{35.5} & \multirow{5}{*}{11} & \multirow{5}{*}{45} & 0.3 \\
\hline $\begin{array}{c}18.1- \\
26.0 \\
\end{array}$ & $\begin{array}{c}\text { Not } \\
\text { good }\end{array}$ & 90 & & & & 9.7 \\
\hline $\begin{array}{c}26.1- \\
34.0 \\
\end{array}$ & Enough & 312 & & & & 33.7 \\
\hline $\begin{array}{c}34.1- \\
42.0 \\
\end{array}$ & Good & 451 & & & & 48.7 \\
\hline $\begin{array}{c}42.1- \\
50.0 \\
\end{array}$ & $\begin{array}{l}\text { Very } \\
\text { good }\end{array}$ & 70 & & & & 7.6 \\
\hline TOTAL & & 926 & & & & 100 \\
\hline
\end{tabular}

Afterward, table 7 shows pleasure in learning for rural schools as many areas as 926 respondents, dominated by good attitude, yes, 451 respondents. So, the students pleasure in learning is categorized good. Then table 7 also states the attitude of the category is not good as much as $9.7 \%$, for the attitude of the category is enough there are $33.7 \%$. Then in the good category that is $48.7 \%$ and the last attitude is very good is $7.6 \%$. From the 926 students having a mean value of 35.5 a maximum value is 45 , and a minimum value is 11 . If seen further, it was found that students' pleasure in learning natural science for junior schools in urban areas is higher than in rural areas.

The results of the interviews said students in categorized well enough known students love to study natural science. For example, students in the class actively ask and dare to deliver answers in front of the class. This can be seen from the results of the interview below.

"Do you enjoy learning natural science? What is the proof"

"Yes I enjoy learning natural science. The proofis I actively ask and do on the whiteboard when asked by the same teacher" (U)

"If given the same task by the teacher when you do it?"

"Night time" $(U)$

"Do your own work by yourselves or by chatting with friends?"

"Do it by myself." (U)

"Do you enjoy learning natural science? What is the proof"

"Yes I enjoy learning natural science. The proof is I actively ask and do on the blackboard when asked by the same teacher" ( $R$ )

"If given the same task by the teacher when you do it?"

"Afternoon time" (R)

"Do your own work by yourselves or by chatting with friends?"

"No, I study together, because not all my friends have books.” (R)

\section{Self-confidence of students in urban and rural}

The result of students' self-confidence in learning of natural science for urban schools is showed by the table 8 , meanwhile for the rural schools is showed by the table 9 .

Table 8. Self-confidence in learning for urban junior high school

\begin{tabular}{|c|c|c|c|c|c|c|}
\hline \multicolumn{3}{|c|}{ Classification } & \multirow{2}{*}{ Mean } & \multirow{2}{*}{ Min } & \multirow{2}{*}{ Max } & \multirow{2}{*}{$\%$} \\
\hline Range & Attitude & Total & & & & \\
\hline $\begin{array}{c}21.0- \\
37.8\end{array}$ & $\begin{array}{c}\text { Not very } \\
\text { good }\end{array}$ & 0 & \multirow{5}{*}{83.5} & \multirow{5}{*}{44} & \multirow{5}{*}{102} & 0.0 \\
\hline $\begin{array}{c}37.9- \\
54.6 \\
\end{array}$ & $\begin{array}{c}\text { Not } \\
\text { good }\end{array}$ & 85 & & & & 9.2 \\
\hline $\begin{array}{c}54.7- \\
71.4\end{array}$ & Enough & 213 & & & & 23.0 \\
\hline $\begin{array}{c}71.5- \\
88.2\end{array}$ & Good & 552 & & & & 59.6 \\
\hline $\begin{array}{c}88.3- \\
105.0\end{array}$ & $\begin{array}{l}\text { Very } \\
\text { good }\end{array}$ & 76 & & & & 8.2 \\
\hline TOTAL & & 926 & & & & 100 \\
\hline
\end{tabular}

Table 8 shows students' self-confidence in learning of natural science for urban schools area as much as 926 respondents, dominated by good attitude, as many as 552 respondents. So, the students' self-confidence in learning is categorized good. Then table 8 also states the attitude of the category is not good as much as $9.2 \%$, for the attitude of the category is enough there are $23 \%$. Then in the good category that is $59.6 \%$ and the last attitude is very good is $8.2 \%$. From the 926 students having a mean value of 83.5 a maximum value is 102 , and a minimum value is 44 .

Furthermore, table 9 shows students' self-confidence in learning of natural science for rural schools area as much as 926 respondents, dominated by good attitude, as many as 496 respondents. So, the students' self-confidence in learning is categorized good. Then table 9 also states the attitude of the category is not good as much as $10.2 \%$, for the attitude of the category is enough there are $31.4 \%$. Then in the good category that is $53.6 \%$ and the last attitude is very good is $4.9 \%$. From the 926 students having a mean value of 77.5 a maximum value is 98.5 , and a minimum value is 40.5 . If seen further, it is found that students' self-confidence in learning natural science for junior schools in urban areas is higher than in rural areas. 
Table 9. Self-confidence in learning for rural junior high school

\begin{tabular}{|c|c|c|c|c|c|c|}
\hline \multicolumn{3}{|c|}{ Classification } & \multirow{2}{*}{ Mean } & \multirow{2}{*}{ Min } & \multirow{2}{*}{ Max } & \multirow{2}{*}{$\%$} \\
\hline Range & Attitude & Total & & & & \\
\hline $\begin{array}{c}21.0- \\
37.8\end{array}$ & $\begin{array}{l}\text { Not very } \\
\text { good }\end{array}$ & 0 & \multirow{5}{*}{77.5} & \multirow{5}{*}{40.5} & \multirow{5}{*}{98.5} & 0.0 \\
\hline $\begin{array}{c}37.9- \\
54.6\end{array}$ & $\begin{array}{c}\text { Not } \\
\text { good }\end{array}$ & 94 & & & & 10.2 \\
\hline $\begin{array}{c}54.7- \\
71.4\end{array}$ & Enough & 291 & & & & 31.4 \\
\hline $\begin{array}{c}71.5- \\
88.2\end{array}$ & Good & 496 & & & & 53.6 \\
\hline $\begin{array}{c}88.3- \\
105.0\end{array}$ & $\begin{array}{l}\text { Very } \\
\text { good }\end{array}$ & 45 & & & & 4.9 \\
\hline TOTAL & & 926 & & & & 100 \\
\hline
\end{tabular}

\section{The Regression}

The results of the influence of attitude with self-confidence students' can be seen in table 10 below.

Table 10. Results of regression

\begin{tabular}{|c|c|c|c|c|c|}
\hline \multirow{2}{*}{ Variable } & \multicolumn{2}{|c|}{$\begin{array}{c}\text { Unstandardized } \\
\text { Coefficients }\end{array}$} & $\begin{array}{c}\text { Standardized } \\
\text { Coefficients }\end{array}$ & $\mathrm{t}$ & sig. \\
\cline { 2 - 6 } & $\mathrm{B}$ & $\begin{array}{c}\text { Std. } \\
\text { Error }\end{array}$ & Beta & & \\
\hline Constant & 17.521 & 3.262 & & 4.820 & .000 \\
\hline Attitude & .142 & .124 & .132 & 2.321 & .019 \\
\hline
\end{tabular}

From table 10, it can be seen the results of a simple regression test found that the regression equation is $\mathrm{Y}=$ $17.521+0.142 \mathrm{X}$, where it is found that attitude influences self-confidence $(B=0.142, \mathrm{p}<0.05)$.

Table 11. Contribution from attitude on self-confidence

\begin{tabular}{|c|c|c|c|c|}
\hline Model & $\mathrm{R}$ & $\mathrm{R}$ square & Adjust R Square & $\begin{array}{c}\text { Std. Error of } \\
\text { the Estimate }\end{array}$ \\
\hline 1 & .840 & .752 & .719 & 2.905 \\
\hline
\end{tabular}

The results of simple regression analysis showed that the value of coefficient of determination was $\left(R^{2}\right) 0.752$, this means that the contribution of attitude to self-confidence skills is $75.2 \%$, while the remaining $24.80 \%$ is influenced by other variables.

\section{Differences in Students' Attitudes and Self-confidence based on Urban and Rural Schools}

To find out whether there is a difference between students ' attitudes and self-confidence in learning natural science based on urban and rural schools' area, an independent sample t-test was used. Table 12 shows the difference between students 'attitude in learning natural sciences based on urban and rural schools' area, meanwhile table 13 shows the self-confidence.

Based on the table 12, result shows that there is differences among students' attitudes in learning natural sciences based on their schools' area $(\mathrm{t}(924)=22.874$, $\mathrm{p}<0.001)$ ), where students who are schooling in urban schools' area $(\mathrm{M}=4.022, \mathrm{SD}=0.13621)$ tent to provide higher attitudes than students who are schooling in rural schools' area $(\mathrm{M}=3.561, \mathrm{SD}=0.19815)$.

Table 12. Independent sample t-test for attitude

\begin{tabular}{|c|c|c|c|c|c|c|c|c|}
\hline & \multirow{2}{*}{$\begin{array}{c}\text { School } \\
\text { Area }\end{array}$} & \multirow{2}{*}{ Mean } & \multirow{2}{*}{ Std. Deviation } & \multirow{2}{*}{$\mathrm{T}$} & \multirow{2}{*}{ df } & \multirow{2}{*}{ Sig. } & \multicolumn{2}{|c|}{$95 \%$ confidence interval } \\
\hline & & & & & & & Lower & Upper \\
\hline \multirow{2}{*}{ Attitude } & Urban & 4.022 & .13621 & 22.874 & 924 & 0.000 & 18.652 & .6120 \\
\hline & Rural & 3.561 & .19815 & 22.863 & 912.074 & & 17.421 & .8615 \\
\hline
\end{tabular}

Table 13. Independent sample t-test for self-confidence

\begin{tabular}{|c|c|c|c|c|c|c|c|c|}
\hline & \multirow{2}{*}{$\begin{array}{c}\text { School } \\
\text { Area }\end{array}$} & \multirow{2}{*}{ Mean } & \multirow{2}{*}{$\begin{array}{c}\text { Std. } \\
\text { Deviation }\end{array}$} & \multirow{2}{*}{$\mathrm{T}$} & \multirow{2}{*}{ df } & \multirow{2}{*}{ Sig. } & \multicolumn{2}{|c|}{$\begin{array}{c}95 \% \text { confidence } \\
\text { interval }\end{array}$} \\
\hline & & & & & & & Lower & Upper \\
\hline \multirow{2}{*}{ Self-confidence } & Urban & 4.019 & .12451 & 21.452 & 924 & 0.000 & 19.425 & .5420 \\
\hline & Rural & 3.494 & .17841 & 21.452 & 917.002 & & 16.281 & .9415 \\
\hline
\end{tabular}


Furthermore, based on the table 13, result shows that there is differences among students' self-confidence in learning natural sciences based on their schools' area $(\mathrm{t}(924)=21.452, \mathrm{p}<0.001))$, where students who are schooling in urban schools' area $(\mathrm{M}=4.019, \mathrm{SD}=0.12451)$ tent to provide higher self-confidence than students who are schooling in rural schools' area $(\mathrm{M}=3.491, \mathrm{SD}=$ $0.17841)$.

\section{Discussion}

Attitude to natural science is a reflective behavior in the learning process. Attitudes toward natural science are considered to be beneficial to a person or situation that results in likes or dislikes [33]. Many factors influence the student's attitude, namely social influence and internal circumstances. Attitudes towards the investigation in natural science conducted on junior high school students in both of urban and rural area has a dominant category attitude that is a good attitude.

Attitudes to the study of natural science show that students love experimental learning. This investigation should learn the skills in solving the problem of one of them doing experiments [15]; [34]. The positive thing about this investigation is that students tend to be more active in finding new things and have a high curiosity to make learning more effective. An Investigations can improve thinking problems [35]. Attitudes toward investigation in natural science are very important in the scope of the school. This is in line with [36]. An important goal of science education is for students to develop interest and support within scientific inquiry, and acquire and apply science and technology for personal, social, and global benefits.

Adoption of the scientific attitude done to junior high school students in both of urban and rural area has a dominant category attitude that is a good attitude. The adoption of a dominant scientific attitude is to listen to the opinions of different people. Because students prefer to exchange different opinions in order to know right and wrong in order to be corrected. A scientific attitude can develop students' useful characters in shaping the life of the scientific community [17]. Scientific attitude is influential in learning. For example, students tired of listening to new ideas do not want to listen to the opinions of others, which makes student learning outcomes low. Factors influencing attitudes are identified from various fields in the ethics and psychology literature [38]. In addition, students have a positive attitude towards the scientific attitude that can change bad habits for the better. Scientific attitude is one of the main areas of concern to a teacher in a class situation in general [39].

Based on the results obtained from the questionnaire data on the pleasure indicators in natural science learning conducted on junior high school students in both of urban and rural area, a dominant category attitude is good. With a good enough attitude in the pleasure of learning in natural science, students are active in the class and want to do their own work. The pleasure of learning depends on the learning process, the student happy in learning will have a positive impact on the teacher. Students say that the teacher while learning is very friendly and understand the concept deeper. It is very important for students to have an experienced conceptual understanding and make the learning situation happy [22]. This positive attitude makes students' learning pleasure improve their learning outcomes. The results of good natural science learning are influenced by the enjoyment of students' science and pleasure given the predictive effect of learning science. In addition, students who have positive emotions associated with pleasure will be successful in learning [39]; [40].

One aspect of personality that shows quality human resources is one's level of self-confidence. Self-confidence has an important function to actualize one's potential. Many problems arise because a person lacks self-confidence, for example, a student who cheats on an exam is one example that the student does not believe in his own abilities, he relies more on others. This illustrates the unpreparedness especially of students in facing exams. The low self-esteem that students have, encourages students to commit fraud in working on exam questions [41]. This is done because of the feelings of stress and anxiety experienced by students for fear of failing and not passing the national exam that has very strict assessment standards. A student who has confidence will try hard in conducting learning activities. Someone who has high confidence has a sense of optimism in achieving something as expected [42]. Conversely, someone who lacks confidence believes that he lacks the ability. Negative assessment of its ability can hamper efforts to be made to achieve the objectives to be achieved. These negative views and judgments cause students not to do any activities with all the capabilities they have [43]. Even though it might actually have the ability.

There is a difference in the value of attitude and self-confidence in urban and rural areas. Seen from these two values, students in urban areas tend to have a high attitude and self-confidence than students in rural areas. This phenomenon can be caused by several factors. Generally, it can be influenced by internal factors and external factors.

Student internal factors are influenced by conditions caused by students themselves. This can be influenced by learning styles, learning motivation [44] on natural science, the trauma of learning natural science. In other cases, it can come from something that keeps students away from learning that comes from students [45].

External factors come from conditions around students. This has a profound effect on the value of attitude and self-confidence of students in urban and rural area schools. There is tendency of students in urban areas to have social, environmental, and supporting facilities when compared to those in schools in rural areas [46]; [47].

\section{Conclusion}

Student attitudes toward natural sciences have good 
values for both urban and rural school areas, but when it comes to comparing them, students in urban tend to get higher attitudes and self-confidence than students in rural area. Regression shows if attitudes affect self-confidence of students. Students who have a good attitude in natural science will influence learning, and make students more confident in learning natural science. If students have a good attitude then they will be more active in the learning process because students have high self-confidence.

\section{Acknowledgements}

The researchers would like to thank all the principals who have been willing to give permission for us to use the school that is managed to be a place of research, and all the partitions that have helped us.

\section{REFERENCES}

[1] K. Wood. "Education the Basics". New York. Touchstone, 2011

[2] A. Astalini., D. A. Kurniawan., U. Sulistiyo., R. Perdana., \& Susbiyanto. "E-Assessment Motivation in Physics Subjects for Senior High School". International Journal of Online and Biomedical Engineering (iJOE), 15(11), 4-15. 2019.

[3] Indonesia, Law on the National Education System, Law No. 20 of 2003

[4] I. Kaniawati., A. Samsudin., Y. Hasopa., A. D. Sutrisno., \& E. Suhendi. "The Influence Of Using Momentum And Impulse Computer Simulation To Senior High School Students' Concept Mastery". In Journal Of Physics: Conference Series Vol. 739, No. 1, 012060. Iop Publishing. 2016.

[5] D. Darmaji., D. A. Kurniawan., \& Irdianti. "Physics education students' science process skills". International Journal of Evaluation and Research in Education (IJERE)", 8(2), 293-298. 2019

[6] C. M. Reigeluth. "Intructional - Design Theories And Models”. New York: Routledge. 2012.

[7] Asrial., Syahrial., D. A. Kurniawan., F. Chan., P. Nugroho., R. A. Pratama., \& R. Septiasari. "Identification: The Effect Of Mathematical Competence On Pedagogic Competency Of Prospective Teacher". Humanitiest \& Social Sciences Reviews (HSSR), 7(4), 85-92. 2019.

[8] S. K. Reddy., \& S. Kumari. "Effect Of Short Term Yoga Practices On Cognitive Function And Attitude Towards Violence In School Children-A Randomized Control Study". Voice Of Research, 3(4), 14-16. 2015.

[9] Astalini., D. A. Kurniawan., Darmaji., L. R. Sholihah., \& R. Perdana. "Characteristics Of Students' Attitude To Physics In Muaro Jambi High School". Humanities \& Social Sciences Reviews (HSSR), 7(2), 91-99. 2019.

[10] S. Liu., \& C. Laohawiriyanon. "Students' Attitudes towards Cultural Learning in the English Classroom: A Case Study of Non-English Major Students in a Chinese University". International Journal of English Language Education. 1(3),
28-42, 2013.

[11] A. Veloo., R. Nor., \& R. Khalid. "Attitude Towards Physics And Additional Mathematics Achievement Towards Physics Achievement". International Education Studies, 8(3), 35-43. 2015.

[12] O. O. Olasimbo. \& C. O. Rotimi. "Attitudes Of Students Towards The Study Of Physics In College Of Education Ikere Ekiti, Ekiti State, Nigeria". American International Journal Of Contemporary Research, 2(12):86. 2012.

[13] Asrial., Syahrial., D. A. Kurniawan., M. Subandiyo., \& N. Amalina. "Exploring obstacles in language learning among prospective primary school teacher". International Journal of Evaluation and Research in Education (IJERE), 8(2), 249-254. 2019.

[14] A. G. Welch. "Using The Tosra To Assess High School Students' Attitudes Toward Science After Competing In The First Robotics Competition: An Exploratory Study". Eurasia Journal Of Mathematics, Science \& Technology Education, 6(3). 2010.

[15] N. G. Lederman., J. S. Lederman., \& A. Antink. "Nature Of Science And Scientific Inquiry As Contexts For The Learning Of Science And Achievement Of Scientific Literacy". International Journal Of Education In Mathematics, Science And Technology, 1(3). 2013.

[16] A. I. Farooq. "Measurement Of Scientific Attitude Of Secondary School Students In Pakistan". Academic Research International, 379-392. 2012.

[17] M. P. Lacap. "The scientific attitudes of students major in science in the new teacher education curriculum". Asia Pacific Journal of Multidisciplinary Research, 3(5), 7-15. 2015.

[18] R. Trumper. "Factors Affecting Junior High School Students' Interest In Physics". Journal Of Science Education And Technology, 15(1), 47-58. 2006.

[19] R. M. D. Guido. "Attitude And Motivation Towards Learning Physics”. Arxiv Preprint Arxiv:1805.02293, 2018.

[20] L. Manasia. "Enjoyment Of Learning In Upper Secondary Education. An Exploratory Research". Procedia-Social And Behavioral Sciences, 180, 639-646. 2015

[21] D. Darmaji., A. Astalini., D. A. Kurniawan., H. Parasdila., Irdianti., S. Hadijah., \& R. Perdana. "Practicum Guide: Basic Physics Based of Science Process Skill". Humanities \& Social Science Reviews (HSSR), 7(4), 151-160. 2019.

[22] R. Maharaj-Sharma., \& A. Sharma. "Using Ict In Secondary School Science Teaching-What Students And Teachers In Trinidad And Tobago Say?". European Journal Of Education Studies. 2017.

[23] A. Astalini., D. Darmaji., H. Pathoni., W. Kurniawan., Jufrida., D. A. Kurniawan., \& R. Perdana. "Motivation and Attitude of Students on Physics Subject in the Middle School in Indonesia”. International Education Studies, 12(9), 15-26. 2019.

[24] A. Astalini., D. Darmaji., W. Kurniawan., K. Anwar., \& D. A. Kurniawan. "Effectiveness of Using E-Module and E-Assessment". International Journal Of Interactive Mobile Technologies, 13(9), 21-39. 2019.

[25] N. Erdemir. "Determining Students' Attitude Towards Physics Through Problem-Solving Strategy". In Asia-Pacific Forum On Science Learning And Teaching, 
10(2), 1-19. 2009.

[26] E. Surya., \& F. A. Putri. "Improving Mathematical Problem-Solving Ability and Self-Confidence of High School Students through Contextual Learning Model". Journal on Mathematics Education, 8(1), 85-94. 2017.

[27] F. N. Kerlinger. "Foundations of behavioral research". Yogyakarta: Gadjah Mada University Press. 2014.

[28] J. W. Cresswel. "Educational Research: Planning, Conducting, And Evaluating Quantitative And Qualitative Research". New York: Pearson, 2012.

[29] L. Cohen., L. Manion., \& K. Morrison. "Research Methods In Education": Routledge, 2007.

[30] A. Astalini., \& D. A. Kurniawan. "Development of Junior High School Student Attitude Instruments Towards Natural Science Subject". Jurnal Pendidikan Sains (Jps), 7(1), 1-7. 2019.

[31] Y. Mantz. "The development and initial use of a survey of student 'belongingness', engagement and self-confidence in UK higher education". Assessment \& Evaluation in Higher Education, 2014. DOI: 10.1080/02602938.2014.990415

[32] M. B, Miles., \& A. M, Huberman. Qualitative data analysis (2nd ed.). Thousand Oaks, CA: Sage. 1994

[33] Maison., Astalini., D. A. Kurniawan., R. Perdana., L. Anggraini. "The Phenomenon of Physicology Senior High School Education: Relationship of Students' Attitudes towards Physics, Learning Style, Motivation". Universal Journal of Educational Research. 7(10), 2199-2207. 2019.

[34] A. Astalini., D. Darmaji., D. A. Kurniawan., R. Melsayanti. "E-Assessment of Student Perception of Natural Science Based on Seska in Middle School Students in Indonesia". International Journal of Scientific \& Technology Reseaerch, 8(9), 858-863. 2019.

[35] Astalini., D. A. Kurniawan., R. Perdana., W. Kurniawan. "Identification Attitudes of Learners on Physics Subjects". Journal of Educational Science and Technology (EST), 5 (1), 39-48. 2019.

[36] R. Bybee., B. Mccrae., \& R. Laurie. "PISA 2006: An Assessment Of Scientific Literacy". Journal Of Research In Science Teaching, 46(8), 865-883. 2009.

[37] S. Al-Rafee., \& T. P. Cronan. "Digital Piracy: Factors That Influence Attitude Toward Behavior". Journal Of Business Ethics, 63(3), 237-259. 2006.

[38] R. Mukhopadhyay. "Scientific attitude-some psychometric considerations". IOSR Journal Of Humanities And Social Science (IOSR-JHSS) OSR-JHSS, 19, 98-100. 2016.

[39] M. A. Ainley. "A Cultural Perspective on the Structure of Student Interest in Science". International Journal of Science Education, 51-71, 2011.

[40] D. Lucardie. "The impact of fun and enjoyment on adult's learning”. Procedia - Social and Behavioral Sciences, 439 446. 2014.

[41] H. Sancar-Tokmak \& T. Yanpar-Yelken. "Effects of creating digital stories on foreign language education pre-service teachers' TPACK self-confidence". Educational Studies, $2015 . \quad$ DOI: 10.1080/03055698.2015.1043978

[42] M. Heo. "Digital Storytelling: An Empirical Study of the Impact of Digital Storytelling on Pre-service Teachers'
Self-efficacy and Dispositions towards Educational Technology." Journal of Educational Multimedia and Hypermedia, 18(4): 405-428, 2019.

[43] I. Sadler. "The role of self-confidence in learning to teach in higher education". Innovations in Education and Teaching International, 50(2), 157-166, 2013. DOI: 10.1080/14703297.2012.760777

[44] D. Panizzon. Teaching secondary science in rural and remote schools: Exploring the critical role of a professional learning community. In D. Corrigan, J. Dillon, \& R. Gunstone (Eds.), The professional knowledge base of science teaching (pp. 173-188). Dordrecht: Springer. 2011.

[45] Govindarajan. "A Study Of Scientific Attitude Among Secondary School Students In Namakkal District”, Shanlax International Journal of Education, 2:3, 85-9, 2014

[46] V. P. Vázquez. "Learning Outcomes in CLIL Programmes: a Comparison of Results between Urban and Rural Environments". Porta Linguarum 29 enero,9-28, 2018.

[47] K. C. Susilawati, Hsiung. "Attitude Toward Science Of Students In Rural And Urban Areas Of School In Aceh Province Of Indonesia". Proceeding of International Conference on Special Education-CAPEU At Syiah Kuala University, Banda Aceh, September 4-6, 2013. 87-95. 2013. 